\title{
The Relationship between Students' Learning Interest and Students' Problem-Solving Skill of Eighth-Grade Students in Learning Mathematics
}

\author{
Anggun Siska Hamidah ${ }^{1, a)}$, Desyarti Safarini $\operatorname{TLS}^{2, \text { b) }}$ \\ ${ }^{12}$ Sampoerna University, South of Jakarta, Indonesia \\ Email: a) anggun.hamidah@my.sampoernauniversity.ac.id, \\ b) desyarti.safarini@sampoernauniversity.ac.id
}

\begin{abstract}
This study aims to determine the relationship between students' learning interests and students' problem-solving skills of eighth-grade students in learning mathematics. Correlational research design is applied in this study whether to determine the relationship between the two variables. The sample consists of 43 eighth-grade students at one of Junior High School in Jakarta academic year 2019/2020. In general, the eighth-grade students dominate at an average level of students' learning interest and students' problem-solving skill with a percentage of $79.07 \%$ and $72.09 \%$, respectively. The SPSS analysis obtained that $r_{x y}$ was 0.405 , which describes a relationship between students' learning interest and students' problem-solving skill of eighth-grade students in learning mathematics. The students' learning interest and students' problem-solving skills have a moderate positive correlation. Since the data are collected online, there will be factors that can be considered as factors that influence students' mathematical problem-solving skills. Thus, the students' learning interest can explain about $16.4 \%$ of the total variation in the students' mathematical problem-solving skills.
\end{abstract}

Keyword: relationship, learning interest, problem-solving skill, mathematics

\section{INTRODUCTION}

Mathematics is one of the most important subjects that students should learn in school, and it also relates to our daily life. Meanwhile, many students think that mathematics is a difficult subject, even they are afraid when they are learning mathematics in the classroom. It is strengthened with research that conducts an interview, and the students stated they feel difficult to understand mathematics and dizzy to solve mathematics problems (Nizami \& Mahmudi, 2018).The Common Core State Standards and Partnership for 21st Century Skills mentioned that people are required to have the problem-solving skill, critical thinking, collaborative learning, integration environment, and digital tools in teaching. In this 21st century, mathematics is one of the lessons that required 21 st-century skill, which is a problem-solving skill. The National Council of Teacher Mathematics (NCTM) mentioned that problem-solving had become an essential skill in mathematics and mathematics education of K-12 students (Bradbury, 2010).

Problem-solving becomes a core in mathematics because students will have limited skill and mathematics ideas if they do not have problem-solving skills. Problem-solving requires students' conceptual understanding which can improve their ability in reasoning and their curiosity. It is emphasized that students must master the core academic subject and 21 st- 
century skills (Prismana, Kusmayadi, \& Pramudya, 2018).The problem-solving skill becomes essential because it can help the students to learn in other fields. After all, they can apply these skills and find solutions to the problems. Problem-solving is a process in solving the problems; it emphasizes the way or strategy of the students rather than the final result (Prismana et al., 2018). The aim is to challenge students' understanding and critical thinking, especially for mathematics lessons.

Based on some studies that have been done, secondary and higher education students still lack information and problem-solving skill (Armaǧan, Saǧir, \& Çelik, 2009). Understanding of mathematical concepts and skills is a prerequisite for a successful in problem-solving. While Meyer (1978) stated understanding of mathematical concepts and skills had not been sufficiently used a successful in problem-solving. Other factors also affect students' problem-solving skill. The influencing factors are learning difficulties, attitudes (like/dislike), attention, feeling lazy, formulas, responses, prior learning, and motivation (Kudsiyah, Novarina, \& Lukman, 2017).

Learning difficulties have the highest influence that is $25 \%$, attitude (likes/dislikes) influences $14.44 \%$, attention influences $9.61 \%$, feeling lazy influences $9 \%$, the formula influences $7.84 \%$, the response has an influence of $7.29 \%$, the learning experience has an influence of $6.76 \%$, and motivation has an influence of $5.76 \%$ (Kudsiyah et al., 2017). Thus, if the students have a lack of problem-solving skill, it can affect their mathematics skill. Mathematics skill is essential for students because it is not only needed when the students in the elementary school, but it is also used as their provisions when they are at the secondary level and further education. Furthermore, Tambychik and Meerah (2010) stated that mathematical skills such as arithmetic, number facts, language and information play an essential role in problem-solving. Thus, if the students lack mathematics skills, it can also affect their problem-solving skill (Tambychik \& Meerah, 2010).

Nowadays, Indonesian students have a low level of mathematics skill which is strengthened by the achievement of Indonesian students' scores in PISA. The data showed that the average of mathematics score in 2012 and 2015; Indonesian students got 375 and 386 (Argina, Mitra, ljabah, \& Setiawan, 2017). While the average score in PISA 2018, Indonesian students got a score 379 for mathematics. Based on the data, it can be seen that Indonesian students' score for mathematics is still below an international average score which is 500. This achievement score also has decreased from 2015 to 2018. Moreover, Trends and International Mathematics and Science Study (TIMSS) report that in 2011 Indonesian students in term of mathematical skills got the average achievement of about 386. While, in 2015, Indonesian students got 397 (Mullis, Martin, Foy, \& Hooper, 2015). Both of PISA and TIMSS data, some problems used mathematical problem-solving.

Based on that, it can be said that mathematics skill can also influence the students' achievement and problem-solving become one of the external factors that influence it. One of the internal factors that affect the students' achievement is students' interest (Khasanah, Usodo, Subanti, Candiasa, \& Santiyadnya, 2017). Endang Kristiyani (2018) stated that interest is a condition in which people found a situation related to their needs and desires. Interest also about people's tendency towards specific tasks, activities and topics. Students' interest has an essential role in learning, which can make the students become diligent and focused. It can also ease the students in following the learning process and solving the given problems.

Judith and Cris (2010) stated that interest is considered as a process that can contribute to learning and achievement. If the students have the interest to follow the learning process, it can make them easy to understand the material and solve mathematics problems even. They will tend to participate, pay attention and engage in the learning activities. Students' interest in learning can undoubtedly be influenced by two factors which are internal and external factors. Fuad and Zuraini (2016) stated that the internal factor is a factor comes from within students that include physical or physical health, attention, observation, 
memory, thinking, and talent can influence student interest in learning. While, the external factor is a factor that comes from outside of the individual, such as the environment which can come from the family, school, and social.

Based on recent research, it was found that eighth-grade students had strong indicators of learning interest in mathematics (Hanipa, 2019). Attention, willingness, needs, feeling happy or joyful feeling, teaching materials, and teacher's good attitudes, and participation during the learning process are the indicators of students' interest (Saswandi , 2014). Arlianty (2017) also stated that students who have interest in learning could be seen from some element such as liking and interest in the things learned, the desire of students to learn, attention to learn, and their enthusiastic, participation and activeness on the learning process. Thus, if a student meets these indicators, it can be identified that the student has a high interest in learning.

Moreover, the author also found that in one of the private junior high school near Pancoran, she found that most of the eighth-grade students seem to have an interest in learning mathematics. Some students pay low attention during teaching and learning of mathematics. Based on these statements, the author curious to know the students' learning interest and students' problem-solving skill of eighth-grade students in learning mathematics. Furthermore, Judith and Cris (2010) stated that learning interests indirectly have a contribution to the students' mathematical problem-solving. So, this study also wants to examine a relationship between students' learning interest and students' problemsolving skill in learning mathematics.

\section{Limitation}

The research was conducted for all eighth-grade students in one of the private junior high school near Pancoran, South of Jakarta. The data will be collected by giving the participants a questionnaire about learning interest and a test about mathematical problem-solving questions directly in the classroom. However, when the author wants to collect the data, it is impossible to do it directly in the school due to the current condition of Covid-19. The author decides to gain the data online by making the questionnaire and the test into Google-form and give a link to the students. During the author collected the data, she cannot directly supervise the students when solving the test, consisting of three non-routine problems and filling out the questionnaire, and this is marked as the first limitation of this study.

Since the data collected online in the predetermined time, the author only use the participants who participate at that time. Thus, she used a convenience sampling method where a method that used a group of individuals who were willing to participate in the study. In the research, the convenience sampling method is not recommended because of the possibility of errors in sampling and not sufficient to generalize the population. Samples collected using this method may not represent the population of interest and can be a source of bias. However, in this case, the author tried to get a larger sample or close to the determined population. In the convenience sampling method, a larger sample size can reduce the possibility of errors in sampling (Bennett et al., 1984). The conclusions obtained in the studies using convenience sampling methods are only based on the sample itself. Therefore, the result obtained in this study were not sufficient to be generalized; this is the second limitation of the study.

\section{METHOD}

This study used the correlational study as its research design which aims to indicate the relationship between two or more variables. By using a statistical correlation test, the author can describe and measure the level of relationship between two or more variable (Creswell, 2012). This study conducted in Junior High School Asisi Tebet, a private junior 
high school located near Pancoran, South of Jakarta, Indonesia. Fifty-seven eighth-grade students were selected as the population. Of the 57,43 students were willing to participate in the study who fill out the questionnaire and solve mathematical problemsolving questions and were used as the sample for this study. The convenience sampling method was applied in this study because data were collected online with a predetermined time due to COVID-19 pandemic. Both instrument and test are two kinds of instruments for the data collection purpose. The instrument aims to measure the students' learning interest, and a test aims to measure the students' problem-solving skill in mathematics. Below are the indicators of students' learning interest that will be used in this study.

TABLE 1. Indicators of Students' Learning Interest

\begin{tabular}{ccccc}
\hline Variable & Indicators & \multicolumn{2}{c}{ Statement } & The Number \\
& & Positive & Negative & of items \\
\hline Students' & Attention & $2,6,12$ & $17,22,26$ & 6 \\
\cline { 2 - 4 } $\begin{array}{c}\text { Learning } \\
\text { Interest }\end{array}$ & Willingness & $3,4,13,15$ & $16,24,29$, & 8 \\
& & $5,10,14$ & $18,25,27$ & 6 \\
\cline { 2 - 4 } & Participation & 20,23 & 4 \\
\cline { 2 - 4 } & $\begin{array}{c}\text { Needs } \\
\text { Feeling happy or } \\
\text { joyful }\end{array}$ & $1,8,11$ & $19,21,28$ & 6 \\
\hline \multicolumn{2}{c}{ Total } & & 30 \\
\hline
\end{tabular}

Attitude scale was used in this questionnaire, which commonly in education research called the Likert Scale. The Likert Scale was used to score the students' learning interest. While, analytic score scale based on Charles, Lester, \& O'Daffer (1987) to assess the students' problem-solving, as depicted in Table 2 below.

TABLE 2. Analytic Score Scale for Assessing Students' Problem-Solving skill Analytic Score Scale

\begin{tabular}{lrl}
\hline \multicolumn{1}{c}{ Problem Solving Phase } & Score & \multicolumn{2}{c}{ Observation or Inference } \\
\hline Understanding the problem & 0 & $\begin{array}{l}\text { Complete misunderstanding of the } \\
\text { problem }\end{array}$ \\
\cline { 2 - 3 } & 1 & $\begin{array}{l}\text { Part of the problem misunderstood or } \\
\text { misinterpreted }\end{array}$ \\
\hline 2 & Complete understanding of the problem \\
\hline 0 & $\begin{array}{l}\text { No attempt, or totally inappropriate plan } \\
\text { Planning a solution }\end{array}$ & $\begin{array}{l}\text { Partially correct plan based on part of the } \\
\text { problem being interpreted correctly }\end{array}$ \\
\hline 2 & $\begin{array}{l}\text { Plan could have led to a correct solution if } \\
\text { implemented properly }\end{array}$ \\
\hline
\end{tabular}


Getting an answer
$0 \quad$ No answer, or wrong answer based on an inappropriate plan

$1 \quad$ Copying error; computational error; partial answer for a problem with multiple answer

2 Correct answer and correct label for the answer

After getting the data from a questionnaire and the test, the author did the instruments validity and reliability analysis, normality testing, find the descriptive statistics, and a hypothesis test by using Statistical Packages for the Social Sciences (SPSS) 2.6 for windows. The basis for decision making was done in several ways. The author will see sig. (2-tailed), where if the value of Sig. (2-tailed) $<0.05$, it can be said there is a correlation between the two variables. Meanwhile, if the value of Sig. (2-tailed) $>0.05$, it can be said that there is no correlation between the two variables. Then, the hypothesis analysis of the variables is conducted the test of the null hypothesis $\left(\mathrm{H}_{0}\right)$ stating that there is no relationship between students' learning interest and students' problem-solving skill of eighth-grade students in learning mathematics. In contrast, the alternative hypothesis $\left(\mathrm{H}_{1}\right)$ is stating that there is a relationship between students' learning interest and students' problem-solving skill of eighth-grade students in learning mathematics.

If the $r_{\text {calculation }}$ is less than $r_{\text {table }}$ then $\mathrm{H}_{0}$ will be accepted and $\mathrm{H}_{1}$ will be rejected. While, if the $r_{\text {calculation }}$ is bigger than $r_{\text {table }}$ then $H_{1}$ will be accepted and $H_{0}$ will be rejected (Wenno, 2015). The correlation coefficient was interpreted whether it is a positive, negative or there is no correlation. The last, the coefficient determination was also defined in order to measure the proportion of variability in one variable that can be determined from the relationship with other variables (Gravetter \& Wallnau, 2013).

\section{FINDINGS AND DISCUSSION Findings}

Based on the instrument analysis by using SPSS 2.6 for windows, 26 valid and four invalid statement items in the questionnaire was obtained. At the same time, three nonroutine problems for the mathematical problem-solving are valid. Both instruments also are said as a reliable instrument and in the normal distribution. Below is the result of a descriptive analysis of students' learning interest and students' problem-solving skill of eighth-grade students in learning mathematics. Then, the result of the score of students' learning interest and students' problem-solving skill classified into three categories, as explained in figure 1.

TABLE 3. Descriptive Analysis of the Learning Interest and Problem-Solving Skill

\begin{tabular}{ccccccc}
\hline & $\mathrm{N}$ & Mean & Median & $\begin{array}{c}\text { Std. } \\
\text { Deviation }\end{array}$ & Minimum & Maximum \\
\hline $\begin{array}{c}\text { Students' Learning } \\
\text { Interest }\end{array}$ & 43 & 65.72 & 66.00 & 12.894 & 29 & 92 \\
\hline $\begin{array}{c}\text { Students' } \\
\text { Mathematical }\end{array}$ & 43 & 12.07 & 13.00 & 3.744 & 0 & 18 \\
\begin{tabular}{c} 
Problem-solving Skill \\
\hline
\end{tabular} & & & & & & \\
\hline
\end{tabular}




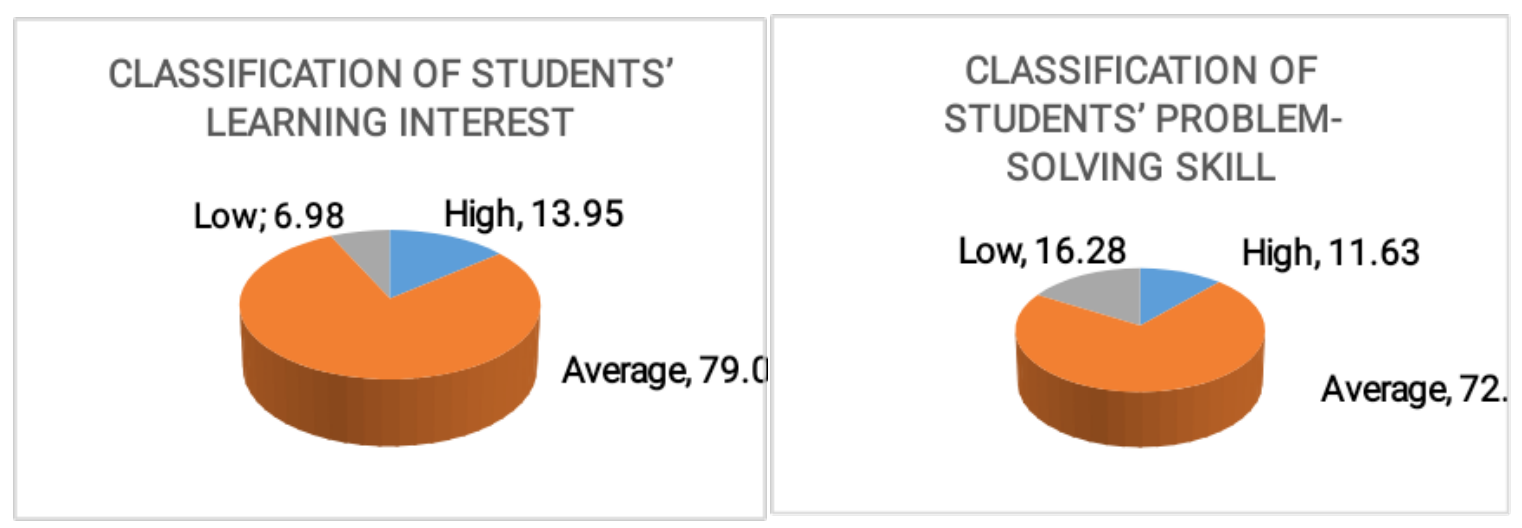

FIGURE 1. Classification of Students' Learning Interest and Students' Problem-Solving Skill

Then, it is continued by the hypothesis testing and the graph of the correlation (scatter plot) between students' learning interest and students' problem-solving skill of eighth-grade students in learning mathematics, as depicted in figure 2. Furthermore, the result of the analysis correlation coefficient between students' learning interest and students' problemsolving skill is presented in table 4.

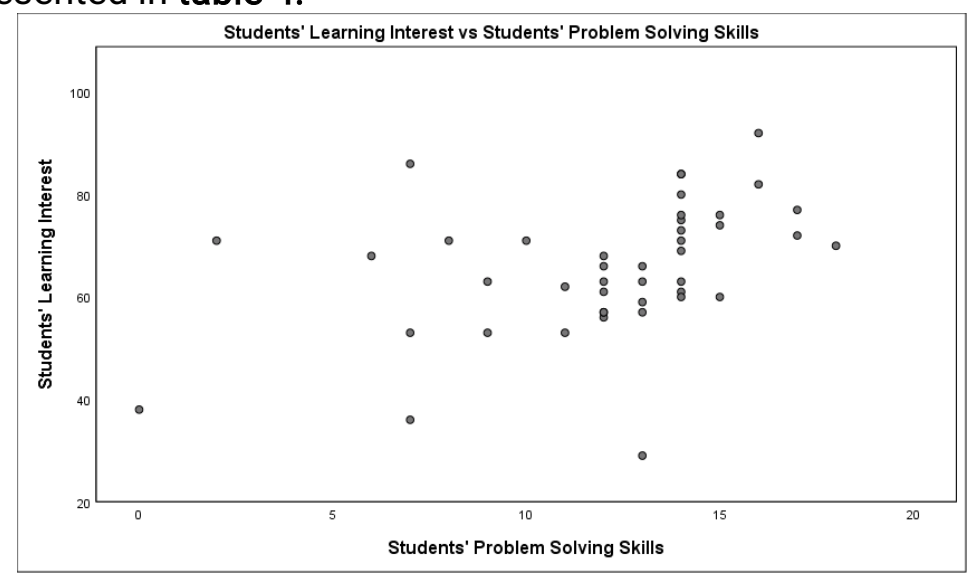

FIGURE 2. The Scatterplot of the Correlation

\begin{tabular}{llr|r}
\multicolumn{3}{c}{ TABLE 4. Correlations } & \multicolumn{1}{c}{$\mathrm{Y}$} \\
\hline $\mathrm{X}$ & Pearson Correlation & 1 & $.405^{* *}$ \\
\cline { 2 - 4 } & Sig. (2-tailed) & 43 & .007 \\
\cline { 2 - 4 } & $\mathrm{N}$ & $.405^{\star *}$ & 43 \\
\hline $\mathrm{Y}$ & Pearson Correlation & .007 & \\
\cline { 2 - 3 } & Sig. (2-tailed) & 43 & 43 \\
\hline & $\mathrm{N}$ &
\end{tabular}

Based on the correlation analysis on table 4, it is obtained that sig. (2-tailed) $0.007<0.05$ which means that there is a significant correlation between students' learning interest and students' problem-solving skill. The coefficient correlation/Pearson Correlation $\left(r_{x y}\right)$ between students' learning interest $(X)$ and students' problem-solving skill 
$(Y)$ is 0.405 . Then, the value of $r^{2}$ is equal to 0.164 which means that $16.4 \%$ of the total variation in the students' problem-solving skill can be explained by the students' learning interest. The $r^{2}$ is the coefficient of determination or the proportion of the variation that can be explained. Based on the coefficient correlation, the $\left(r_{x y}\right) \neq 0$ meaning that there is a correlation between students' learning interest and students' problem solving skill. Then, the Pearson Correlation shows a positive correlation because $r_{x y}>0$ and it is also bigger than the $r_{\text {table }}$. Therefore, there is a sufficient evidence to claim that the null hypothesis $\left(\mathrm{H}_{0}\right)$ is rejected and the alternative hypothesis $\left(\mathrm{H}_{1}\right)$ is accepted.

\section{Discussion}

Based on both a questionnaire and a test, the participants tend to dominate at an average level for the students' learning interest and problem-solving skill. The results obtained, there were $79.07 \%$ of students who are at an average level category for the learning interest. There are still $6.98 \%$ of students in the low-level category, and $13.95 \%$ have high learning interest. Thus, it can be concluded that in general, students' learning interest dominates at the average level. As said before, Arliyanti (2017) mentions that interest is about people's tendency towards specific tasks, activities, and topics. Indicators of interest are defined as attention, willingness, participation, need, and feeling happy or joyful toward something. Thus, if a student meets these indicators, it can be identified that the student has a high interest in learning.

High or low student's interest in learning can also be influenced by several factors, such as learning habits. Students with high learning interests will tend to have good study habits. They will continue to learn and find out the things they like and are interested in. Thus, they will also have a high willingness to participate in the learning process. While students with low interest, there is a possibility they have unfavourable learning habits. Furthermore, Lusi Marleni (2016) said that student's concentration ability in learning, the influence of peers when learning in the classroom, the delivery of material during the learning process, and learning media could also influence learning interest. These factors can also be influential factors for students' learning interest.

The mathematical problem-solving skill test was also conducted to the students. Problem-solving skill is known as a process in solving a problem, while it more emphasizes students' strategy or way of finding the solution rather than the result (Prismana et al., 2018). From the results obtained, in general, this eighth-grade students also dominates mathematical problem-solving skill at an average level. There were $72.09 \%$ of students who are at an average level category for the mathematical problem-solving skill. Then, the remainder, which is about $11.63 \%$ of students have a high level of mathematical problem-solving skill and $16.28 \%$ of students still at the low category of mathematical problem-solving skill.

The data shows that students who have low mathematical problem-solving skill tend to be higher than students with high problem-solving skill. The students who are at the low level of mathematical problem-solving skill, it can be caused they have learning difficulties, such as in understanding the mathematical problem-solving questions and errors in calculating. According to the previous research, it is known that learning difficulties have an effect of $25 \%$ in the mathematical problem-solving skill. Learning difficulties are an inability to mastering the concepts and algorithms, even though they have tried to learn it. Difficulties faced by the students in problem-solving are analyzing problems, understanding problems, the process of solving the problems, forgetting formulas, and errors in calculating (Kudsiyah et al., 2017).

Besides, learning experiences, mastery of the material, feeling lazy, and attitudes (like/dislike) also influence the level of students' mathematical problem-solving skill (Kudsiyah et al., 2017). These factors can also be factors that influence students' 
mathematical problem-solving skill. There is a student who was not able to perform any solution for the given problem-solving questions. The student is also included in the category of students who have low learning interest. Meyer (1978) said that understanding of mathematical concepts and skills is indeed a prerequisite for a successful problemsolving. However, these two things have not been sufficiently used as a successful problem-solving. It can also be influenced by other factors, such as learning interest.

Moreover, Lester (1985) stated that besides sufficient knowledge, a successful problem-solving also depends on when and how someone can utilize it. Then, based on the correlation analysis result by using SPSS 2.6 for windows, it was obtained that the Pearson correlation coefficient was 0.405 . The Pearson Correlation coefficient $\left(r_{x y}\right)$ shows that the relationship between students' learning interest and students' problem-solving skill exists. This coefficient correlation is not much different with the coefficient correlation in the study about "Problem-solving ability of the adolescents in relation to their interest in science" which is 0.494 . Then, the value of $r^{2}$ resulted 0.164 , which mean that students' learning interest can explain about $16.4 \%$ of the total variation in the students' mathematical problem-solving skill. In comparison, $83.6 \%$ might be explained by other factors.

$83.6 \%$ of the total variation in the students' mathematical problem-solving skill might be explained by factors such as learning difficulties, laziness, their attention, and others. Since the data for this study were collected online, these factors can be considered as factors that influence students' mathematical problem-solving skill. When the author gives the test to the students, there is a possibility that laziness can arise from them. They are lazy to solve the given problems since the author or their teacher did not supervise them. Thus, it makes the students not careful and careless in solving the given problems. Learning difficulties such as understanding of mathematical problem-solving questions can also occur because they did not understand the problems.

Related to the research conducted by Siti, Eka, and Hamidah (2017), affective aspects also influence mathematical problem-solving skill. These affective aspects emphasize the aspects of feelings, such as interests, attitudes, appreciation, and ways of adjustment shown during the learning process. Their finding indicates that affective aspects in general, have the most significant influence on mathematical problem-solving skills, which is $13 \%$. The affective aspects, such as students' attention, influence $9.61 \%$, which means students' attention indicates their interest in learning (Kudsiyah et al., 2017). Besides, there is also another affective aspects, such as feeling lazy and learning experience, which has an influence of $9 \%$ and $6.76 \%$ on mathematical problem-solving skills, respectively. Thus, the findings of this study define that the relationship between students' learning interests and students' problem-solving skills exists and considered a moderate positive correlation.

Furthermore, a positive correlation can be interpreted that the higher the student's interest, the higher level of student's ability to solve mathematical problem-solving questions. However, the results obtained do not sufficiently indicate that interpretation, there was a student who had a high interest in learning, but had a low mathematical problem-solving skill. Since the mathematics problems are given online, the student can have difficulty in understanding the questions given. So she/he did not know how to solve these problems and could not ask the teacher or researcher. On the other hand, because the student felt no one was supervising, she/he felt lazy to solve these problems. So that makes her/him answer carelessly. It can be considered as a factor that causes students who have an interest in learning mathematics but have low achievement in solving mathematical problems. While there are also students with low interest but get results on a relatively good mathematical problem-solving skill.

This can happen when the students solve the given problems, and they are motivated to 
solve it because they are supervised by their parents or are with people who can help them in understanding the questions. So, it can make it easier to solve the problems. Online data retrieval can cause many factors that can affect the data. Moreover, Judith and Cris (2010) stated that interest could contribute to learning and achievement. If the students have an interest in the learning, they are expected to have a good mathematical problemsolving skill. However, based on the result in this study, it shows that interest in learning is not the only factor influencing problem-solving skill. Other factors can influence students' problem-solving skill. Therefore, the relationship between students' learning interest and students' problem-solving skill of eighth-grade students in learning mathematics was considered a moderate correlation.

\section{CONCLUSION}

Based on the result of the study, the students' learning interest and students' problemsolving skill of the eighth-grade students, in general, dominates on the average level with the percentage of $79.07 \%$ and $72.09 \%$, respectively. Furthermore, there is a relationship between students' learning interest and students' problem-solving skill of eighth-grade students in learning mathematics. Since the data were collected online, there will be factors that can be considered as factors that influence students' mathematical problemsolving skill. Thus it was obtained the coefficient correlation is 0.405 , which means students' learning interest and students' problem-solving skill in learning mathematics have a moderate positive correlation. The students' learning interest can explain about $16.4 \%$ of the total variation in the students' mathematical problem-solving skill. In comparison, $83.6 \%$ might be explained by other factors such as learning difficulties, laziness, learning experience, and others.

\section{RECOMMENDATION}

Based on the result, the author present some recommendations. To get a more accurate problem-solving ability test results, further research can be done by giving the test and questionnaire directly in the classroom. So, the researchers can maintain when the students solve the test and fill the questionnaire. In addition, the researchers can also add interview methods to the some students to obtain additional information related to students' interest in learning and their ability to solve mathematical problem-solving.

\section{ACKNOWLEDGEMENT}

Firstly, thank you to Allah SWT, who always give me the strength, so this manuscript entitled 'The relationship between students' learning interests and students' problemsolving skill of eighth-grade students in learning mathematics" could be done. Secondly, I would also like to express my gratitude towards Miss Desyarti Safarini TLS. M.Si, thank you for being my advisor and help me to finish this manuscript. Moreover, thank you to my lecturers and friends who have helped in this research. 


\section{REFERENCES}

Argina, A. W., Mitra, D., ljabah, N., \& Setiawan, R. (2017). Indonesia PISA Result: What Factors and What Should be Fixed? The 1st Educational and Language International Conference Proceedings Center for International Developmentof Unissula, 69-79.

Arlianty, W. N. (2017). An analysis of interest in students learning of physical chemistry experiment using Scientific approach. International Journal of Science and Applied Science: Conference Series, 1(2), 109. https://doi.org/10.20961/ijsascs.v1i2.5130

Armağan, F. Ö., Sağir, Ş. U., \& Çelik, A. Y. (2009). The effects of students' problem solving skills on their understanding of chemical rate and their achievement on this issue. Procedia - Social and Behavioral Sciences, 1(1), 2678-2684. https://doi.org/10.1016/j.sbspro.2009.01.473

Bradbury, J. (2010). Why is Teaching with Problem Solving Important to Student Learning? Nctm, 13(12), 1-6.

Creswell, W. J. (2012). Planning, Conducting, and Evaluating Quantitative And Qualitative Research. Lincoln.

Fuad, Z. Al, \& Zuraini. (2016). Faktor-faktor Yang Mempengaruhi Minat Belajar Siswa Kelas 1 SDN Kute Padang. Jurnal Tunas Bangsa, 3(2), 42-54.

Gravetter, F. J., \& Wallnau, L. B. (2013). Statistics for the Behavioral Sciences. United States of America: Jon-David Hague.

Hanipa, A. (2019). ANALISIS MINAT BELAJAR SISWA MTS KELAS VIII DALAM PEMBELAJARAN MATEMATIKA MELALUI APLIKASI GEOGEBRA. JPMI (Jurnal Pembelajaran Matematika Inovatif), 2(5), 315. https://doi.org/10.22460/jpmi.v2i5.p315 $-322$

Harackiewicz, J. M., \& Hulleman, C. S. (2010). The Importance of Interest: The Role of Achievement Goals and Task Values in Promoting the Development of Interest. Social and Personality Psychology Compass, 4(1), 42-52. https://doi.org/10.1111/j.17519004.2009.00207.x

Kaur, B. (2008). Problem solving in the mathematics classroom (Secondary). National Institute of Education.

Khasanah, V. N., Usodo, B., Subanti, S., Candiasa, I. M., \& Santiyadnya, N. (2017). Enhancing Students 'Interest through Mathematics Learning Enhancing Students ' Interest through Mathematics Learning.

Kristiyani, E. (2018). Increasing interest and mathematical learning outcome in mathematic of trigonometry basic competence $(K D)$ by using reciprocal teaching model for students of class X MIPA 4 SMA Negeri 5 Magelang in the even semester of academic year 2017/2018. 2(1), 142-149. https://doi.org/10.31002/ijel.v2i1.1057

Kudsiyah, S. M., Novarina, E., \& Lukman, H. suryani. (2017). Faktor-Faktor Yang Mempengaruhi Kemampuan Pemecahan Masalah Matematika Kelas X Di Sma Negeri 2 Kota Sukabumi. Education: Prodi Pendidikan Matematika FKIP Universitas Muhammadiyah Sukabumi, 110-117.

Marleni , L. (2016). Faktor-faktor yang Mempengaruhi Minat Belajar Siswa Kelas VIII SMP Negeri 1 Bangkinang. Journal Cendikia: Jurnal Pendidikan Matematika, 149-159.

Mullis, I. V. S., Martin, M. O., Foy, P., \& Hooper, M. (2015). TIMSS 2015 International Results in Mathematics.

Nizami, A. W., \& Mahmudi, A. (2018). Problem-solving-based learning to improve students' learning interest. AIP Conference Proceedings, 2014(September). https://doi.org/10.1063/1.5054450

Prismana, R. D. E., Kusmayadi, T. A., \& Pramudya, I. (2018). Analysis of difficulties in mathematics problem solving based on revised Bloom's Taxonomy viewed from high self-efficacy. Journal of Physics: Conference Series, 1008(1). https://doi.org/10.1088/1742-6596/1008/1/012063 
Tambychik, T., \& Meerah, T. S. M. (2010). Students' difficulties in mathematics problemsolving: What do they say? Procedia - Social and Behavioral Sciences, 8(5), 142-151. https://doi.org/10.1016/j.sbspro.2010.12.020

Saswandi , T. (2014). Teaching Style and Students' Interest in Learning English.

Wenno, I. H. (2015). The Correlation Study of Interest at Physics and Knowledge of Mathematics Basic Concepts towards the Ability to Solve Physics Problems of 7th Grade Students at Junior High School in Ambon Maluku Province, Indonesia. Education Research International, 2015, 1-6. https://doi.org/10.1155/2015/396750 